\title{
PERILAKU PENGUNJUNG LAPANGAN PUPUTAN DALAM PENERAPAN PERDA NOMOR 1 TAHUN 2014 TENTANG KAWASAN TANPA ROKOK (KTR) DI KABUPATEN KLUNGKUNG TAHUN 2017
}

\author{
Ni Putu Sona Kharisma*, Ni Komang Ekawati, I Made Kerta Duana \\ Program Studi Kesehatan Masyarakat Fakultas Kedokteran Universitas Udayana \\ *Email: sonakharisma61@gmail.com
}

\begin{abstract}
ABSTRAK
Upaya pemerintah dalam mengendalikan permasalahan rokok adalah dengan melakukan regulasi tentang peraturan pemerintahan. Kab. Klungkung merupakan salah satu Kabupaten di Bali yang telah mengadopsi Perda KTR yang ditetapkan dalam Peraturan Daerah Nomor 1 tahun 2014 tentang Kawasan Tanpa Rokok. Pemerintah Daerah Kab. Klungkung sangat berkomitmen untuk menurunkan angka perokok dengan mengadopsi Perda KTR dan membuat aturan mengenai larangan iklan rokok, namun kenyataannya tingkat kepatuhan masyarakat terhadap Perda KTR di tempat umum masih rendah. Tujuan penelitian ini adalah untuk mengetahui perilaku pengunjung Lapangan Puputan Kab. Klungkung dalam penerapan Perda Nomor 1 tahun 2014 tentang Kawasan Tanpa Rokok, dengan menggunakan metode penelitian kualitatif. Sampel dalam penelitian ini dipilih dengan metode purposive sampling dan jumlah informan dalam penelitian ini adalah 10 orang dan 2 orang informan kunci. Dari 10 informan tersebut terdiri dari 5 informan merupakan perokok dan 5 informan bukan perokok, pengumpulan data dilakukan dengan wawancara mendalam dan observasi. Berdasarkan hasil penelitian dapat diketahui bahwa pengetahuan informan terkait Perda KTR di Lapangan Puputan Kab. Klungkung masih kurang dan persepsi informan mengenai pelaksanaan Perda KTR di Lapangan Puputan Klungkung termasuk negatif. Selain itu ketersediaan tanda KTR masih minim, serta peran dari Dinas Kesehatan dan Satpol PP masih belum efektif dalam penerapan Perda tersebut. Disimpulkan bahwa pengetahuan, persepsi, ketersediaan tanda, dan peran Dinas Kesehatan dan Satuan Polisi Pamong Praja (Satpol PP) terkait Perda KTR di Lapangan Puputan Kabupaten Klungkung masih kurang sehingga mempengaruhi perilaku informan terhadap kebiasaan merokok di tempat umum, oleh sebab itu Dinas Kesehatan Kabupaten Klungkung disarankan untuk melaksanakan sosialisasi ke desa-desa dan Satpol PP agar lebih tegas melakukan pengawasan, dan untuk peneliti selanjutnya agar meniliti determinan-determinan lain.
\end{abstract}

Kata kunci: Perilaku, Perda KTR, Kawasan Tanpa Rokok

\begin{abstract}
Government efforts in controlling the problem of cigarettes is to make regulations on government regulations. Klungkung is one of the regencies in Bali that has adopted a KTR Regional Regulation stipulated in Regional Regulation No. 1 of 2014 concerning No-Smoking Areas. Government of Klungkung District is very committed to reducing the number of smokers by adopting the KTR regulation and making rules regarding the prohibition of cigarette advertising, but in reality the level of public compliance with the KTR regulation in public places is still low. The purpose of this study was to determine the behavior of visitors Puputan Field in Klungkung District in the application of Perda No. 1 of 2014 concerning No-Smoking Areas, by using qualitative research methods. The sample in this study was selected by the method of purposive sampling and the number of informants in this study were 10 people and 2 key informants. Of the 10 informants consisting by 5 smokers and 5 non-smokers, data collection is done by in-depth interviews and observation. Based on the results of the study it can be seen that the informant's knowledge related to the Regional Regulation on KTR in Puputan Field in Klungkung is still lacking and informants' perceptions regarding the implementation of the Regional Regulation on KTR in Puputan Field in Klungkung are negative. In addition, the availability of KTR markings is still minimal, and the role of the Health Office and Satpol PP is still not effective in the application of the regulation. It was concluded that knowledge, perception, availability of signs, and the role of the Health Office and the Civil Service Police Unit (Satpol PP) related to the Regional Regulation on KTR in Puputan Field in Klungkung were still lacking so that it influenced the informant's behavior towards smoking habits in public places, therefore the Klungkung District Health Office It is recommended to carry out socialization to villages and Satpol PP to be more assertive in conducting supervision, and for further researchers to examine other determinants.
\end{abstract}


Keywords: Behavior, Regional Regulation on KTR, Non-Smoking Area

\section{PENDAHULUAN}

Merokok merupakan sebuah kebiasaan yang dapat merugikan kesehatan baik untuk para pelakunya sendiri maupun orang lain di sekelilingnya. Yang patut disayangkan adalah masih rendahnya kesadaran masyarakat perokok akan bahaya asap rokok yang mereka hembuskan terhadap orang-orang sekelilingnya yang tidak merokok, atau yang lazim disebut perokok pasif.

Menurut The Tobacco Atlas 3rd Edition (dalam Infodatin, 2014) terkait persentase penduduk dunia yang mengkonsumsi tembakau didapatkan sebanyak $57 \%$ pada penduduk Asia dan Australia, 14\% pada penduduk Eropa Timur dan pecahan Uni Soviet, $12 \%$ penduduk Amerika, 9\% penduduk Eropa Barat, dan $8 \%$ pada penduduk Timur Tengah serta Afrika. Sementara itu ASEAN merupakan sebuah kawasan dengan $10 \%$ dari seluruh perokok dunia dan $20 \%$ penyebab kematian global akibat tembakau.

Menurut Riset Kesehatan Dasar (2013) peningkatan jumlah perokok di Indonesia, yaitu dari 34,2\% tahun 2007 menjadi 36,3\% pada tahun 2013 (64,9\% laki-laki dan 2,1\% perempuan). Perilaku merokok menjadi Upaya pemerintah Indonesia dalam mengendalikan permasalahan rokok ini adalah dengan melakukan regulasi tentang peraturan pemerintahan.

Dalam undang-undang ini tertuang pula pasal yang menyebutkan bahwa pemerintah daerah wajib untuk menetapkan KTR di wilayahnya.

Provinsi Bali merupakan wilayah yang turut menerapkan regulasi KTR ini.
Peraturan KTR ini ditetapkan dalam Perda No. 10 tahun 2011 tentang Kawasan Tanpa Rokok. Menurut Survey BTCI tahun 2016 di Bali, tingkat kepatuhan masyarakat Bali terhadap aturan KTR masih kurang yaitu sebesar 70,6\% pada survey pertama dengan target yang harus dicapai sebesar $80 \%$.

Kabupaten Klungkung merupakan salah satu Kabupaten di Bali yang telah mengadopsi Perda KTR yang mana ditetapkan dalam Perda Nomor 1 tahun 2014 tentang Kawasan Tanpa Rokok. Pemerintah Daerah Kabupaten Klungkung sangat berkomitmen untuk menurunkan angka perokok dengan mengadopsi Perda KTR dan membuat aturan mengenai larangan iklan rokok, selain itu adapula program dari Dinas Kesehatan yaitu melakukan sosialisasi terkait KTR. Namun kenyataannya tingkat kepatuhan masyarakat terhadap Perda KTR di tempat umum masih rendah. Berdasarkan Survey BTCI tahun 2016 di Kab. Klungkung, tingkat kepatuhan masyarakat Klungkung terhadap aturan KTR yaitu sebesar 72,9\%. Tempat umum menjadi kawasan dengan tingkat kepatuhan terendah di antara tempat-tempat lainnya. Tempat umum yang dimaksud yaitu pasar modern, pasar tradisional, tempat wisata, tempat hiburan, hotel, restoran, tempat rekreasi dan/atau olah raga, halte, terminal angkutan umum, terminal angkutan barang dan pelabuhan.

Salah satu tempat umum yang ada di Kab. Klungkung adalah Lapangan Puputan Klungkung. Lapangan Puputan Klungkung yang dimaksud adalah tempat rekreasi dan/atau olah raga. Definisi pengunjung menurut KBBI adalah orang yang mengunjungi suatu tempat. Lapangan 
Puputan merupakan salah satu tempat yang banyak dikunjungi masyarakat baik dari orang tua, dewasa, remaja maupun anakanak.

Dari hasil study pendahuluan yang dilakukan peneliti dengan melakukan observasi di lingkungan Lapangan Puputan Klungkung masih didapatkan orang yang merokok dan ditemukan puntung rokok dilingkungan Lapangan Puputan tersebut. Untuk itu peneliti tertarik melihat bagaimana perilaku pengunjung Lapangan Puputan dalam penerapan Perda Nomor 1 Tahun 2014 tentang Kawasan Tanpa Rokok di Kab. Klungkung tahun 2017.

Tujuan penelitian ini adalah untuk mengetahui perilaku pengunjung Lapangan Puputan dalam penerapan Perda Nomor 1 tahun 2014 tentang Kawasan Tanpa Rokok di Kab. Klungkung.

\section{METODE}

Rancangan penelitian yang digunakan dalam penelitian ini adalah kualitatif. Sampel yang digunakan adalah informan dan key informan. Informan dalam penelitian ini adalah pengunjung yang ada di Lapangan Puputan Kab. Klungkung. Sedangkan key informan adalah Pemegang Program Dinas Kesehatan dan Satpol PP. Pemilihan informan dilakukan dengan teknik purposive sampling yaitu sampel yang dipilih dengan cermat hingga relevan dengan design penelitian.

Dalam penentuan key informan dilakukan dengan mempertimbangkan sampel yang lebih memiliki informasi yang mendalam terkait penerapan Perda KTR di Lapangan Puputan Kab. Klungkung.

\section{HASIL}

\section{Karakteristik}

5 informan yang merupakan perokok semua berjenis kelamin laki-laki dan berusia berkisar 22 sampai 37 tahun dengan sebagian besar berpendidikan terkahir SMA, 5 informan bukan perokok terdiri dari 3 perempuan dan 2 laki-laki dengan usia yang beragam mulai dari 16 sampai 59 tahun, 5 informan tersebut sebagian besar berpendidikan terakhir SMA.

\section{Pengetahuan}

Pengetahuan mengenai pengertian Kawasan Tanpa Rokok diketahui oleh semua informan perokok. Namun pengetahuan mengenai pengertian Kawasan Tanpa Rokok diartikan sebagai area atau kawasan yang dinyatakan dilarang untuk kegiatan merokok saja. Hal itu dapat dilihat pada kutipan berikut:

\section{“...Kawasan tidak boleh merokok (I-01), (I-05)"}

Adapun pengetahuan sebagian besar informan bukan perokok mengenai Kawasan Tanpa Rokok mendapatkan hasil yang sama yaitu diartikan sebagai area atau kawasan yang dinyatakn dilarang untuk merokok saja, hal ini dapat dilihat pada kutipan berikut:

“...Kawasan yang dilarang untuk merokok ditempat itu (I-07), (I-08)"

Selain itu salah satu informan bukan perokok memiliki pengertian lain tentang Kawasan Tanpa Rokok seperti kutipan berikut:

$$
(I-06)^{\prime \prime}
$$

“...tempat yang tanpa asap rokok

Menurut informan pengunjung yang merokok di Lapangan Puputan Kabupaten Klungkung mengenai pengetahuan tentang 
Isi Perda KTR, semua informan mengatakan tidak mengetahui mengenai isi dari Perda KTR, yang dapat dilihat dari kutipan berikut:

“...Gak tahu, belum pernah ada sosialisasi tentang itu (I-01), (I-02), (I03)"

Terdapat pula 3 informan bukan perokok yang mengatakan tidak mengetahui isi dari Perda KTR, sesuai kutipan berikut:

“...isi peraturannya kurang tau ya (I-06), (I-07), (I-10)"

Namun terdapat 2 informan bukan perokok yang mengetahui isi dari Perda KTR namun tidak dapat menyebutkannya secara lengkap, dapat dilihat pada kutipan berikut:

“...isi tempat dimana gak boleh ngerokok terus kalo melanggar kena sanksi lima puluh juta dan dipenjara tapi gak tau berapa tahun yah (I-09)"

Hasil penelitian yang dilakukan mengenai tujuan dari penerapan Perda KTR adalah untuk melindungi perokok pasif, hal tersebut dapat dilihat dalam kutipan informan perokok sebagai berikut:

“...Untuk melindungi perokok pasif (I-01), (I-03), (I-05)"

Terdapat pula hasil penelitian yang dilakukan mengenai tujuan penerapan Perda KTR dengan informan bukan perokok di Lapangan Puputan Klungkung didapatkan hasil sebagian besar informan mengatakan tujuan penerapan Perda KTR adalah untuk membuat kondisi lingkungan menjadi sehat dan bersih tanpa asap rokok sesuai kutipan berikut:

“...untuk membuat kondisi ditempat itu menjadi sehat dan bersih tanpa asap rokok sehingga udara atau lingkungan sekitarnya disekitar itu tetep selalu sehat tidak mengganggu orang lain (I-07), (I-08), (I-09), (I-10)"

Hasil penelitian terhadap informan perokok di Lapangan Puputan Klungkung sebagian besar dari mereka mengatakan tidak mengetahui adanya Perda KTR di Lapangan Puputan Klungkung dilihat dari pernyataan berikut:

“...Ndak, kebetulan saya liat gininya kan gak ada ya deket-deket sini gak ada larangan makanya saya liat-liat (I-01), (I-03), (I-05)"

Terdapat satu informan perokok yang mengatakan mengetahui adanya Perda KTR di Lapangan Puputan Klungkung, hal tersebut dilihat dari kutipan berikut:

“...Tau, kan itu disana ada tulisannya kawasan tanpa rokok. (I-02)"

Selain itu, salah satu informan mengatakan tahu mengenai Lapangan Puputan Klungkung merupakan salah satu tempat umum tetapi informan tersebut tidak mengetahui tentang adanya Perda KTR di Lapangan Puputan, seperti pada kutipan berikut:

$$
\text { “...Kalo dilapangan ini }
$$
dipergubnya ada sih daerah tempat umum. Tapi disini gak pernah liat sih peraturannya. (I-04)" 
Pengetahuan informan bukan perokok yang mengunjungi Lapangan Puputan Klungkung didapatkan hasil bahwa sebagian besar tidak mengetahui adanya Perda KTR di Lapangan Puputan, sesuai dengan kutipan betikut:

“...Gak tau (I-06), (I-07), (I10)"

Namun terdapat 2 informan yang mengetahui adanya Perda KTR di Lapangan Puputan Klungkung, hal ini dapat dilihat pada kutipan berikut:

$$
\text { “...Tau... (I-08), (I-09)" }
$$

Hasil penelitian kepada informan pengunjung perokok Lapangan Puputan Klungkung mengenai Sanksi bila melanggar Perda KTR diketahui sebagian besar informan tidak mengetahui mengenai sanksi yang diberikan bila melanggar Perda KTR. Pernyataan tersebut dapat dilihat pada kutipan berikut:

“...Belum tau sama sekali ada sanksi (I-01), (I-05)"

Diketahui pengetahuan informan bukan perokok mengenai sanksi yang didapat bila melanggar Perda KTR yaitu terdapat sebagian besar informan mengetahui adanya Perda KTR seperti denda Rp 50.000 dan kurungan pidana, hal tersebut dapat dilihat pada kutipan berikut:

“...Kalo sanksi pernah dengar untuk yang orang melanggar merokok di KTR dendanya lima puluh ribu (I-07), (I08)"

Selain itu dua informan perokok memiliki pandangan yang negatif terhadap pelaksanaan Perda KTR di Lapangan Puputan Klungkung, sesuai dengan kutipan: “...Saya kira enggak efektif kalo tidak ada yang mengontrol banyakan perokok itu cuek aja...Kalo seperti dikasi tanda larangan, dipake larangan itu disini aja kalo kita datang dari timur itu gak liat jadinya (I-01)"

Hasil penelitian yang dilakukan oleh 5 informan perokok yang mengunjungi Lapangan Puputan Klungkung didapatkan hasil yang beragam dimana diketahui dua informan memiliki pandangan yang positif terhadap pelaksanaan Perda KTR di Lapangan Puputan Klungkung, hal ini dapat dilihat pada kutipan berikut:

"...Emmm, sebenernya bagus sih ada aturan begitu, tapi kalo banyak yang gak tau ada aturan gitu kan percuma, terus yang jagain juga gak ada jadi gak ada yang ngasi peringatan. (I-02)"

Pada informan bukan perokok didapatkan hasil bahwa pandangan positif dari penerapan Perda KTR yaitu dengan mendukung adanya Perda KTR di Lapangan Puputan Klungkung. Hal tersebut dapat dilihat pada kutipan berikut;

“...emang itu cukup efektif tapi kasian juga untuk yang perokok karna uang lima puluh juta gak sedikit terus dipenjara juga gak enak karna kesalahan kecil. Mungkin harus dikurangi lagi untuk sanksinya, seperti ditegur untuk langgaran pertama terus kalo lagi melanggar baru kenakan sanksi ya paling gak lima ratus ribu cukup (I-09)" 
Adapun persepsi dari informan bukan perokok yang mengatakan bahwa pelaksanaan Perda tersebut belum efektif karena rendahnya pengetahuan masyarakat terkait adanya Perda KTR di Lapangan Puputan Klungkung, hal ini dapat dilihat pada kutipan berikut:

“...sangat mendukung sanksi yang diberikan pada perokok supaya mengurangi orang-orang yang tidak merokok menghirup asap rokok. Belum begitu efektif karna hanya beberapa orang saja yang tau tentang sanksi tersebut (I06), (I-07), (I-08)"

Hasil penelitian yang dilakukan kepada 5 informan perokok terkait adanya tanda KTR di Lapangan Puputan diketahui sebagian besar informan tidak mengetahui adanya tanda KTR tersebut, seperti pada kutipan berikut:

“...Ndak pernah liat (I-01), (I-

03)"

Tetapi terdapat pula 2 informan perokok yang mengetahui adanya tanda KTR di Lapangan Puputan, dilihat dari kutipan berikut:

“...Ada itu disana. (I-02)"

Hasil penelitian yang dilakukan kepada 5 informan bukan perokok mengenai adanya tanda KTR di Lapangan Puputan diketahui sebagian besar tidak mengetahui adanya tanda KTR, dapat dilihat pada kutipan:

“...Ndak, lapangan kan tempat terbuka masak iya ada begitu (I-06)"
Namun terdapat 2 informan yang mengetahui adanya tanda KTR tersebut, hal ini dapat dilihat pada kutipan berikut:

$$
\text { “...Ada (I-08), (I-09)" }
$$

Faktor pemungkin lain seperti adanya pelaksaan sosialisasi KTR didapatkan hasil bahwa pada sebagian besar informan mengatakan tidak pernah ada pelaksanaan sosialisasi KTR di Lapangan Puputan Klungkung, sesuai dengan kutipan berikut:

"...Tidak pernah ada sosialisasi. (I-03), (I-04), (I-05)"

Adapun hasil wawancara yang dilakukan pada 5 informan bukan perokok terkait pelaksaan sosialisasi KTR di Lapangan Puputan diketahui 2 informan mengatakan tidak pernah ada sosialisasi. Kutipan tersebut dapat dilihat dibawah ini: "...Kalo yang itu setahu saya belum pernah ada sosialisasi (I-06), (I-07)"

Dan sebagian besar tidak mengetahui ada atau tidaknya pelaksanaan sosialisasi KTR di Lapangan Puputan Klungkung, sesuai kutipan berikut:

“...Kurang tahu ya...(I-09)"

“...Gak tahu, sering tak denger ada sosialisasi disini tiap hari minggu tapi gak tau apa itu (I-08), (I-10)"

Terkait faktor penguat pengunjung dalam penerapan Perda KTR seluruh informan perokok mengetahui peran dari pemegang program Dinas Kesehatan.

Dari hasil wawancara mendalam yang dilakukan kepada 5 informan perokok diketahui sebagian besar informan perokok tidak mengetahui peran dari Satpol PP dan 
diharapkan Satpol PP lebih tegas dalam melakukan pengawasan, hal ini dapat dilihat pada kutipan:

“...Tidak tau peran satpol PP. Ya karna satpol PP yang bertugas harusnya dia yang mengarahkan (I-01), (I-05)"

Hasil penelitian terhadap 5 informan perokok yang mengunjungi Lapangan Puputan Klungkung terkait peran Satpol PP di Lapangan Puputan Klungkung dimana seluruh informan bukan perokok mengetahui peranan Satpol PP seperti mengawasi, mengingatkan, dan melakukan sidak terkait penerapan Perda KTR di Lapangan Puputan Klungkung, dilihat pada kutipan berikut:

“...Mengawasi perda biar tidak ada yang melanggar, kayaknya belum soalnya kan belum ada yang terjaring padahal banyak yang merokok (I-06), (I10)"

\section{DISKUSI}

Perilaku merokok adalah aktivitas seseorang yang merupakan respon orang tersebut terhadap rangsangan dari luar yaitu faktor-faktor yang mempengaruhi seseorang untuk merokok dan dapat diamati secara langsung.

Berdasarkan hasil penelitian yang dilakukan oleh peneliti mengenai perilaku pengunjung Lapangan Puputan dalam Penerapan Perda Nomor 1 Tahun 2014 tentang Kawasan Tanpa Rokok (KTR) di Kab. Klungkung yaitu didapatkan 10 informan dengan 5 informan perokok aktif yang merupakan laki-laki dan 5 informan tidak perokok yang sebagian besar perempuan.
Dalam teori perubahan perilaku seseorang menurut Lawrence Green (1980), perilaku dapat dipengaruhi oleh 3 faktor yaitu faktor predisposisi (predisposing factor), faktor pendukung (enabling factor), faktor pendorong (reinforcing factor). Dimana dalam faktor predisposisi tersebut tedapat aspek karakteristik individu, pengetahuan dan persepsi individu. Karakteristik individu salah satunya jenis kelamin seseorang yang sangat mempengaruhi perilaku informan untuk merokok, menurut Global Youth Tobacco Survey(GYTS) yaitu dari 2074 responden pelajar Indonesia usia $15-20$ tahun, 43.9\% mengaku pernah merokok dan $63 \%$ merupakan seorang laki-laki hal ini sesuai dengan hasil penelitian yang dilakukan bahwa sebagian besar informan perokok yang mengunjungi Lapangan Puputan Klungkung merupakan laki-laki.

Pengetahuan merupakan salah satu faktor predisposisi, pengetahuan adalah hasil dari "tahu" dan ini terjadi setelah orang melakukan penginderaan terhadap objek tertentu. Penginderaan terjadi melalui panca indera manusia, yaitu indera penglihatan, pendengaran, penciuman, rasa dan raba. Sebagian besar, pengetahuan manusia diperoleh dari mata dan telinga. Pengetahuan atau kognitif merupakan domain yang sangat penting dalam membentuk tindakan seseorang (overt behavior) (Notoatmodjo, S. 2007).

Dari hasil penelitian yang dilakukan sebagian besar informan memiliki pengetahuan yang baik, semua informan dapat menyebutkan bahaya merokok antara lain kanker, serangan jantung, impotensi, serta gangguan kehamilan. Hal itu sesuai dengan teori yang menyebutkan bahaya 
rokok yaitu rokok merupakan penyebab utama penyakit mematikan seperti kanker paru, stroke, jantung, dan gangguan pembuluh darah, kebutaan, impotensi, juga menurunkan kesuburan, meningkatnya kasus kehamilan di luar kandungan, pertumbuhan janin terlambat, kejang pada kehamilan, gangguan imunitas bayi, dan peningkatan kematian prenatal (Herqutanto, 2008).

Namun pengetahuan mengenai pengertian Kawasan Tanpa Rokok diartikan sebagai area yang dinyatakan dilarang untuk kegiatan merokok serta tempat tanpa asap rokok, sedangkan definisi dari kawasan tanpa rokok menurut Kementerian RI (2011), Kawasan Tanpa Rokok adalah ruangan atau area yang dinyatakan dilarang untuk kegiatan merokok atau kegiatan memproduksi, menjual, mengiklankan, dan/atau mempromosikan produk tembakau.

Berdasarkan hasil dari wawancara mengenai isi dari perda KTR seluruh informan perokok tidak mengetahuinya, namun terdapat dua informan bukan perokok mengetahui isi dari perda KTR tetapi tidak dapat menyebutkan secara lengkap, sedangkan untuk tujuan penerapan Perda seluruh informan mengatakan tujuannya adalah untuk membuat kondisi lingkungan menjadi sehat dan bersih tanpa asap rokok serta melindungi perokok pasif dan mengurangi perokok aktif, hal itu sesuai dengan pernyataan yang mengatakan tujuan dari adanya perda KTR walaupun informan tidak dapat menyebutkan lima poin pokok dari tujuan penerapan KTR, dimana terdapat lima poin dari tujuan peneran perda KTR menurut Kementrian RI (2011) yaitu (1) Menurunkan angka kesakitan dan atau angka kematian dengan cara mengubah perilaku masyarakat untuk hidup sehat; (2) Meningkatkan produktivitas kerja yang optimal; (3) Mewujudkan kualitas udara yang sehat dan bersih, bebas dari asap rokok; (4) Menurunkan angka perokok dan mencegah perokok pemula; (5) Mewujudkan generasi muda yang sehat.

Adapun pengetahuan mengenai tempat-tempat yang termasuk dalam Perda KTR seluruh informan dapat menyebutkannya namun tidak secara lengkap. Kawasan Tanpa Rokok menurut Perda Kabupaten Klungkung No 1 Tahun 2014 meliputi fasilitas pelayanan kesehatan, tempat proses belajar mengajar, tempat anak bermain, tempat ibadah, angkutan umum, tempat kerja, tempat umum dan tempat lain yang ditetapkan. Selain itu hanya terdapat 2 informan bukan perokok yang mengetahui bahwa Lapangan Puputan termasuk dalam Kawasan Tanpa rokok dan hanya terdapat 1 informan perokok saja yang mengetahui adanya Perda KTR, hal itu tidak sesuai dengan informasi dari informan kunci yang mengatakan sudah pernah dilaksanakan sosialisasi terkait penerapan Perda KTR. Mengenai sanksi yang diberikan sebagian informan tidak mengetahuinya, namun terdapat sebagian informan lain yang mengetahui dari sanksi yang diberikan terdapat pelanggaran perda KTR.

Menurut penelitian yang dilakukan di RSUP Dr. Kariadi Semarang (Solicha, 2012) berjudul Tingkat Pengetahuan dan Sikap Pengunjung di Lingkungan RSUP Dr. Kariadi tentang Kawasan Tanpa Rokok menggunakan desain penelitian observasional yang dilakukan dengan 
pendekatan cross sectional dan tehnik pengambilan sampel adalah simple random sampling dan didapatkan jumlah responden sebanyak 90 orang. Data dikumpulkan menggunakan kuesioner. Diketahui sebanyak $38.9 \%$ responden memiliki tingkat pengetahuan baik dan $48.9 \%$ cukup. Dari seluruh responden, ada $85.6 \%$ responden bersikap patuh, sedangkan $14.4 \%$ nya tidak. Analisis hubungan antara keduanya didapatkan nilai signifikan $\mathrm{p}$ adalah 0.001 . Kategori tingkat pengetahuan kategori baik dan sikap patuh memiliki prosentase lebih besar dibanding kategori kurang, terdapat hubungan antara tingkat pengetahuan dan sikap mematuhi aturan yang berlaku.

Selain itu faktor predisposisi selanjutnya adalah persepsi individu, dilihat dari hasil penelitian pada informan mengenai persepsi pengunjung perokok di Lapangan Puputan Klungkung mendapatkan hasil bahwa pandangan informan perokok terhadap pelaksanaan Perda KTR di Lapangan Puputan Klungkung didapatkan hasil positif maupun negatif dan terdapat juga sebagian besar informan bukan perokok yang memiliki pandangan negatif, pandangan positif berupa yang mendukung pelaksanaan Perda, persepsi positif ini terbentuk karena masyarakat sendiri sudah mengetahui dan memahami mengenai tujuan dan manfaat dari Perda ini. Menurut Tjiptojuwono dalam Wuryaningsih, T. (2008), sekali pengetahuan ini terbentuk lewat pengalamannya maka akan menjadi dasar dalam seseorang mempercayai suatu objek tertentu. Sedangkan pandangan negatif muncul karena anggapan ketidakefektifan Perda KTR tersebut. Hal ini sesuai dengan hasil wawancara mendalam yang dilakukan dengan informan kunci, dimana diketahui sikap dan tanggapan masyarakat tentang Perda KTR pada umumnya meneriman dengan adanya Perda KTR namun pada masyarakat yang merokok masih memerlukan penyesuaian terhadap adanya Perda KTR tersebut.

Pandangan terhadap pengunjung lain yang merokok di Lapangan Puputan Klungkung sebagian besar beranggapan bahwa pengunjung tersebut tidak mengetahui ataupun tidak paham terkait pemberlakuan perda KTR di Lapangan tersebut, sedangkan berdasarkan hasil wawancara mendalam dengan informan kunci terkait dengan pemberlakuan Perda KTR diketahui bahwa sosialisasi mengenai Perda KTR sudah dilakukan sejak tahun 2015. Terkait keefektifan sanksi bila melanggar Perda Nomor 1 tahun 2014 tentang Kawasan Tanpa Rokok sebagian besar informan perokok maupun bukan perokok merasa tidak efektif.

Faktor Pendukung (enabling factor) mencakup ketersediaan sarana dan prasarana atau fasilitas kesehatan bagi masyarakat. Mengenai sarana dan prasarana/fasilitas di Lapangan Puputan klungkung sebagai faktor pendukung salah satunya adalah tanda KTR, dimana sebagian besar informan perokok maupun bukan perokok tidak mengetahui keberadaan tanda KTR tersebut namun hanya sebagian kecil yang mengetahui adanya tanda KTR. Menurut hasil observasi yang dilakukan di Lapangan Puputan Klungkung oleh peneliti diketahui tanda KTR dipasang disebelah selatan lapangan yang dekat dengan pintu masuk dan tempat bermain anak, dimana 
tanda tersebut menghadap ke utara sehingga tidak dapat terlihat jelas oleh pengunjung yang masuk. Hal itu tidak sesuai dengan pernyataan yang tertuang pada Perda Kab. Klungkung Nomor 1 Tahun 2014 tentang Kawasan Tanpa Rokok yang menyebutkan bahwa memasang tandatanda dan pengumuman dilarang merokok sesuai persyaratan di semua pintu masuk utama dan di tempat-tempat yang dipandang perlu dan mudah terbaca dan/atau didengar baik.

Agar media lebih efektif dan tepat pada sasaran yang akan dituju, sebaiknya media tersebut memiliki ciri, akurat dalam isi, berpenampilan menarik dan dengan biaya murah, sehingga informasi yang disampaikan dapat diterima secara efektif dan adanya perubahan perilaku, sikap dan keyakinan pada sasaran. Dasar pertimbangan pemilihan media promosi kesehatan adalah (1) karakteristik sasaran/ kelompok, harus memperhatikan latar belakangnya misalnya pendidikan karena akan mempengaruhi informasi (2) Metode atau media bisa diterima tidak oleh sasaran, (3) Luasnya populasi, (4) Kondisi wilayah (5) Biaya, waktu, dan hambatan yang ada, (6) SDM untuk pelaksanaannya (jumlah SDM yang tersedia, kemampuan SDM dalam menggunakan metode dan media). Kemm \& Close (1995) memaparkan bahwa mengembangkan dan memproduksi suatu media/ material program mahal di waktu dan uang. Sehingga biaya untuk mengembangkan materials terebut seharusnya menjadi bagian dari pembiayaan dalam proses dan alokasi program.

Dilihat dari hasil penelitian informan terkait faktor pendukung lain seperti adanya pelaksaan sosialisasi KTR didapatkan hasil bahwa pada seluruh informan perokok maupun bukan perokok mengatakan tidak pernah ada dan tidak tahu terkait pelaksanaan sosialisasi KTR di Lapangan Puputan Klungkung, hal itu tidak sejalan dengan hasil wawancara mendalam yang dilakukan dengan informan kunci selaku Pemegang Program dari Dinas Kesehatan yang bertugas untuk melakukan sosialisasi yang menyatakan bahwa sudah dilakukannya sosialisasi pada saat kegiatan Car Free Day. Selain itu menurut Wied Hary A. (1996) dalam Rahayu, N. (2012), informasi akan memberikan pengaruh pada pengetahuan seseorang. Meskipun seseorang memiliki pendidikan yang rendah tetapi jika ia mendapatkan informasi yang baik akan dapat meningkatkan pengetahuan seseorang. Seseorang yang mempunyai sumber informasi yang lebih baik banyak akan memberikan pengetahuan yang jelas.

Menurut penelitian yang dilakukan di Fakultas Kedokteran Gajah Mada (Siswatibudi, 2015) berjudul Program Promosi Kesehatan Dalam Upaya Penerapan Kawasan 100\% Bebas Asap Rokok Di Fakultas Kedokteran Universitas Udayana didapatkan hasil bahwa ada dukungan yang positif dari pengambil kebijakan (Dekan FK UGM) tentang perlunya SK Dekan baru yang memperjelas penerapan SK Dekan No. UGM/KU/4078/UM/01/39 tentang Kampus Kedokteran UGM sebagai kawasan Bebas Asap Rokok. Hal ini sebagai bukti bahwa metode advokasi, cukup efektif digunakan. Pemasangan media sosialisasi Kawasan Bebas Rokok akan mencapai tujuan membutuhkan waktu yang cukup untuk mengukur efektif tidaknya media tersebut. 
Adapun faktor yang ketiga yaitu faktor pendorong yang diteliti terkait dalam pembentukkan perilaku masyarakat adalah adanya peran serta pengelola (Pemegang Program Dinas Kesehatan) dan pengawas (Satpol PP) yang turut menunjukan perilaku mereka dalam penerapan Perda KTR. Dimana seluruh informan perokok maupun bukan perokok mengetahui peran dari pemegang program Dinas Kesehatan adalah melakukan sosialisasi. Peran Pengelola tersebut masuk dalam faktor-faktor yang mempengaruhi perilaku dimana peran pengelola yaitu petugas kesehatan sebagai pemegang program Kawasan Tanpa Rokok sangat berpengaruh terhadap perilaku masyarakat, disini peran petugas kesehatan yaitu sebagai sumber informasi yang dapat menyebarkan pesan kesehatan kepada seluruh masyarakat agar mampu mempengaruhi masyarakat untuk berperilaku hidup sehat.

Peran satpol PP merupakan faktor pendorong lainnya, sebagian besar informan bukan perokok mengetahui peran Satpol PP yaitu untuk mengawasi dari pelaksanaan Perda, mengingatkan/menegur pengunjung yang merokok di Kawasan Tanpa Rokok dan melakukan sidak-sidak di tempattempat yang termasuk dalam Kawasan Tanpa Rokok. Disini peran Satpol PP masih kurang karena belum mampu mengontrol perilaku masyarakat yang merokok di lingkungan Lapangan Puputan, hal ini sesuai dengan peran pengawas yaitu dengan mengontrol perilaku masyarakat agar mau mengikuti peraturan yang ada. Adapun alasan dari satpol PP tersebut tidak dapat menjalankan perannya sebagai pengawas dalam Perda KTR karena terdapat beberapa hambatan yaitu Satpol PP tidak dapat melakukan pemantauan setiap hari pengunjung yang melanggar Perda KTR, disamping itu karena personil yang dimiliki sedikit.

Menurut penelitian di Provinsi DKI Jakarta, DI Yogyakarta dan Bali (Rahajeng, 2015) berjudul Pengaruh Penerapan Kawasan Tanpa Rokok Terhadap Penurunan Proporsi Perokok di Provinsi DKI Jakarta, DI Yogyakarta dan Bali dengan rancangan studi ekologi, diketahui bahwa penerapan kebijakan KTR atau Kawasan Dilarang Merokok (KDM) berpengaruh terhadap penurunan proporsi perokok setiap hari. Faktor yang ikut berperan adalah komitmen pemeritah daerah; penegakan hukum yang konsisten; pengawasan yang dilakukan secara rutin; kepatuhan stakeholder; dukungan positif dari sektor pendidikan dan sektor pariwisata; serta peran aktif organisasi masyarakat.

\section{SIMPULAN}

Berdasarkan hasil penelitian dapat disimpulkan hasil, pengetahuan pengunjung Lapangan Puputan Klungkung mengenai adanya Perda KTR masih kurang, selain itu persepsi terkait pelaksanaan Perda KTR sebagian besar negatif. Ketersediaan tanda KTR di Lapangan masih minim dan sosialisasi terkait Perda KTR masih kurang. Adapun peran dari pemegang program Dinas Kesehatan dan Satpol PP Kab. Klungkung masih kurang. Artikel ini diharapkan dapat memberikan masukan kepada pemegang program Dinas Kesehatan untuk merencakanan program promosi kesehatan dan Satpol PP untuk dapat 
mengawal pelaksanaannya dan memastikan tidak terjadi pelanggaran.

\section{DAFTAR PUSTAKA}

Azmi, dkk. (2016). Hubungan Penerapan Kawasan Tanpa Rokok (KTR) Dengan Perilaku Merokok Mahasiswa Kesehatan Masyarakat di Kota Semarang. Jurnal Kesehatan Masayarakat Vol 4 Nomor 3 Edisi Juli 2016 halaman 995 - 1004, Available: http://ejournals1.undip.ac.id/index.php/jkm

(Accessed : 2017, August 17)

Azkha, N. (2013). Studi Efektivitas Penerapan Kebijakan Perda Kota Tentang Kawasan Tanpa Rokok (KTR) Dalam Upaya Menurunkan Perokok AKtif Di Sumatera Barat Tahun 2013. Jurnal Kebijakan Kesehatan Indonesia Vol 02 Nomor 4 Edisi Desember 2013 halaman 171-179, Available: http://journal.ugm.ac.id/index.php/jk ki/article/view/3201 (Accessed: 2017, August 20)

Bustan, M.N. (2007). Epidemiologi Penyakit Tidak Menular. Edisi kedua. Jakarta: Rineka Cipta.

KBBI. (2014). "Kamus Besar Bahas Indonesia". Available: http://kbbi.web.id (Accessed: 2017, January 26).

Kemenkes RI. (2011). Pedoman Pengembangan Kawasan Tanpa Rokok. Jakarta: Promkes Kemenkes RI.

Nasution. (2003). Metode Penelitian Naturalistik Kualitatif. Bandung: Tarsito.

Notoatmodjo, S. (2007). Promosi Kesehatan dan Ilmu Perilaku. Jakarta: Rineka Cipta.
Notoatmodjo, S. (2010). Metodologi Penelitian Kesehatan. Jakarta: Rineka Cipta.

Pemerintahan Provinsi Bali. (2001). "Peraturan Daerah Provinsi Bali No. 3 Tahun 2001 Tentang Desa Pakraman". Denpasar: Biro Hukum Dan HAM Setda Provinsi Bali.

Pemerintahan Provinsi Bali. (2011). "Perda No.10 Tahun 2011 Tentang Kawasan Tanpa Rokok". Bali

Pemerintahan Kabupaten Klungkung. (2014). "Perda Nomor 1 Tahun 2014 Tentang Kawasan Tanpa Rokok". Klungkung

Riskesdas. (2013). Riset Kesehatan Dasar 2013. Jakarta: Kemenkes RI.

Rahajeng, E. (2015). Pengaruh Penerapan Kawasan Tanpa Rokok Terhadap Penurunan Proporsi Perokok Di Provinsi DKI Jakarta, Daerah Istimewa Yogyakarta Dan Bali. Jurnal Ekologi Kesehatan Vol 14 Nomor 3 Edisi September 2015 halaman : 238-249, Available

http://ejournal.litbang.depkes.go.id/i ndex.php/jek/article/view/4694

(Accessed : 2017, August 17)

Sadikin, Z.D., dkk. (2008). "Program Berhenti Merokok". (Disertasi). Departemen Farmakologi dan Terapeutik. Jakarta: Fakultas Kedokteran Universitas Indonesia.

Sugiyono. (2008). Memahami Penelitian Kualitatif. Bandung: Alfabeta.

Swarjana, K. (2013). Metodologi Penelitian Kesehatan. Yogyakarta: ANDI

Siswatibudi, H. (2015). Program Promosi Kesehatan Dalam Upaya Penerapan Kawasan 100\% Bebas Asap Rokok Di Fakultas Kedokteran Universitas Gadjah 
Arc. Com. Health Desember 2018

ISSN: 2527-3620

Vol. 5 No. $2: 60$ - 72

Mada. Jurnal Permata Indonesia Vol 6

Nomor 1 Edisi Mei 2015 